\title{
Commentary
}

\section{Why recording workforce mobility matters}

Fiona Haslam McKenzie The University of Western Australia

Email: fiona.haslam-mckenzie@uwa.edu.au. Address: Department of Geography, School of Social Sciences, The University of Western Australia, 35 Stirling Highway, Crawley, Western Australia 6009, Australia

Paper received 12 April 2021; accepted 3 May 2021; published 31 May 2021

\section{Introduction}

There is considerable literature documenting the peripatetic preferences of Australians for leisure, lifestyle and work purposes, and the paucity of reliable data that would provide insights to why people have multiple bases and the impact on local markets and service delivery (McKenzie et al. 2008 p.4; Nicholas and Welters 2017; Nicholas and Welters 2016). There have been numerous requests and submissions to the Australian Bureau of Statistics (Productivity Commission 2014; Productivity Commission 2019; ABS 2007; McKenzie et al. 2008) to systematically record population mobility, and to not limit the Place of Usual Residence to just one location in the quinquennial census. To date, these have been unsuccessful.

This paper focuses specifically on long distance commuting (LDC) for work purposes in rural, regional and remote areas, but the principles and benefits of recording labour force mobility (requiring multiple nights away from the place of usual residence), apply equally for other forms of population mobility such as for education, lifestyle and other seasonal vacation work. Specifically, this paper shows how the lack of data about workforce mobility undermines prescient planning and informed regional economic development for local government authorities whose capacity to raise revenue is limited. This is particularly the case in mining regions where local governments and other planning authorities are constrained by State Agreements which absolve large multinational mining companies from paying local government rates and other taxes for local infrastructure and services (Horsley 2013).

While most of the research and media attention regarding (LDC) has focused on the resources industries, it has been reported that it is not the only sector that broadly utilises LDC. Greer and Stokes (2011) showed that a range of industry sectors utilise LDC, with government, especially the health and education workforce, dominating mobile workers based on per head of population commuting over long distances and staying away from home for consecutive nights. Similar findings by the Productivity Commission $(2019,2014)$ reinforce the scale and breadth of labour LDC across a range of sectors. The practice is now widespread across both public and private sector service delivery, including health, education, telecommunications, transport services and construction in rural, regional and remote communities (Hussain et al. 2015; House of Representatives Standing Committee on Regional Australia 2013; Carson et al. 2011). However, it is the resources industries' LDC practices that have attracted 
most concern and where the impacts are especially acute, especially in remote locations with limited accommodation and services (Ellem and Tonts 2017; Haslam McKenzie 2016b). For example, in 2011 the Pilbara Development Commission (2012) calculated there were 50,388 transit worker accommodation (TWA) beds in the region while the total estimated residential population of the Pilbara was 48,610 people (ABS 2012). "By 2015, the Western Australian Legislative Assembly (2015) estimated that more than 67,000 mining and construction workers commuted to Western Australianbased mine sites, more than the entire population of the Pilbara region" (Haslam McKenzie 2020a p.4). The Pilbara region in north west Western Australia, like most of Australia's resource regions, is located long distances from regional and urban centres where the labour and the workforce is generally concentrated. Western Australian, the largest of the six states, is one of the most economically productive, with rich deposits or mineral resources contributing $15 \%$ of gross national product (GNP) in 2019-20 (Department of Jobs Tourism Science and Innovation 2021), almost 50\% higher than its population share of $10.4 \%$ (ABS 2020). The mining sector's contribution to gross state product (GSP) dwarfs every other industry sector, exceeding all the other sectors combined (Department of Jobs Tourism Science and Innovation 2021). Mining activity is almost as important in Queensland, contributing a further $11 \%$ to GNP (Queensland Treasury 2020). However, despite more and bigger regional centres in Queensland, workforce mobility exerts ongoing pressures (Cheshire 2010; Fleming and Measham 2015). This is particularly so in the more remote Bowen Basin where non-resident workers in the coal industry and industry support services constitute approximately $20 \%$ of the population, which in 2020 equated to 28,758 TWA beds (Queensland Government Statistician's Office 2020).

\section{Capturing long distance commuting data in the census}

For a variety of reasons (Nicholas and Welters 2016; Nicholas and Welters 2017; Haslam McKenzie, 2020b), the workforce servicing the resource industries has favoured LDC whereby workers leave their resident or source community and live away from home in a host community, (usually considerable distance away), returning (typically, several days or weeks later) for furlough. While at work, the workforce lives in company-provided accommodation with meals, entertainment, and transport to and from the mine site, and have limited, if any, interaction with the host community. The length of the rosters ('swings') is often determined by the particular resource being extracted, and whether the employee works fulltime on an ongoing operation or as a contractor with shorter time commitments on a particular site.

Despite the media attention and more recent public policy focus (Productivity Commission 2014; House of Representatives Standing Committee on Regional Australia 2013; House of Representatives Select Committee on Regional Development and Decentralisation 2018), it is difficult to know the scale of the LDC workforce and the impacts of worker mobility. This is because workforce mobility is not accurately counted or measured. Consistent and regular accounting of non-resident populations would provide answers to questions such as: whether or not there is a problem with unaccounted LDC; if the practice is the cause of deleterious impacts on host communities, particularly resourcesbased mono-economy communities; or conversely, if repatriated salaries from the resources industries have a positive multiplier effect when they are spent in other places, particularly rural, regional and remote locations where job opportunities are constrained. 
The Australian Productivity Commission (2014) reported that LDC constitutes only two per cent of the Australian workforce based on work undertaken by KPMG (2013). However, there are many researchers who dispute that conservative figure (McIntosh 2012; Western Australian Legislative Assembly Education and Health Standing Committee 2015; Storey 2016). Definitive data on the residential distribution and mobility of the LDC workforce is difficult to obtain because, to date, the Australian Bureau of Statistics (ABS) does not collect information specific to the LDC workforce. There are also obstacles to obtaining sufficiently comprehensive workforce data from all companies sourcing labour from a given area. Nonetheless, indicative estimates of LDC populations are developed by calculating the differences between Place of Usual Residence and Place of Work census counts (ABS 2012; KPMG for the Minerals Council of Australia 2013) for specific ABS spatial units at given points in time.

Accuracy is diminished by the lack of clarity regarding the description of particular job classifications. While it is generally accepted that the operational workforce of a resource project who regularly commute on a fixed roster are LDC workers, there are many contractors who also commute but their tenure at a particular location or workplace is highly variable and therefore difficult to accurately capture in the data (Haslam McKenzie 2016a). It is likely that over the last two decades, which have witnessed a prolonged mining boom with considerable spill-over effects into the broader Western Australian economy, many construction workers, exploration staff, engineers, transport workers and work camp employees were all contractors on mine sites under construction, but their census data was unlikely to be recorded as linked to the mining industry (McIntosh 2012). Furthermore, the scale of the LDC workforce is potentially obscured by counting only those in the work cycle of rosters and excluding those workers on furlough (McIntosh 2012). Contractors are more likely to work intensely while the work is available and then spend time at home between jobs or contracts (Haslam McKenzie et al. 2013). Furthermore, their commuting work pattern is often highly erratic depending upon work availability and access to transport and accommodation (see Hoath and Pavez 2012).

The census could be modified, as shown in Figure 1, to capture information about people who occupy multiple places for a variety of reasons by simply asking for locality information and what proportion of 'overnight' time is spent at the respective locations and for what reason (leisure, lifestyle or work purposes). It would also be useful to know how people move between different locations, providing information that would guide timely transport infrastructure investment and future planning.

While this paper has focused on labour mobility, the usefulness of the proposed questions is not limited to non-metropolitan locations or communities overwhelmed by non-resident workers. Understanding the scale of second home ownership and the duration of stays in non-resident communities would assist local government authorities that experience seasonal population growth regardless of the reason (including seasonal agricultural labour demand, holiday peaks in coastal and other high amenity areas, and ongoing worker long distance commuting). 
[1] Are you regularly away from home requiring you to stay away multiple nights?

[] No

[2] What is the reason for you regularly staying away from your usual residence?

[ ] Lifestyle (second home)

[ ] Long distance commuting for work purposes

[] Education and training purposes

[ ] Health and wellbeing

[] Leisure

[ ] Other reasons

[3] Do you work away in blocks of time?

[] No

[ ] Yes (write in regular blocks of time in number of nights spent away from home)

[ ] Yes (but blocks of time away are irregular/contract work)

[4] Do you have a second residence?

[] No

[] Yes (the location)

[5] How many nights per year do you spend at the second residence?

[6] Which locality (in Australia) do you spend most time when not living at home?

[7] How do you travel to the other residence/or workplace away from home?

[ ] Aeroplane/helicopter

[] Vehicle

[] Boat

Figure 1: Proposed census questions on multiple places of residence

Source: author

\section{Why accurate data matters}

There has been considerable interest in how LDC impacts local socio-economic performance for both source and host communities (House of Representatives Standing Committee on Regional Australia 2013; Lawrie et al. 2011; Haslam McKenzie 2016a, 2020b; Productivity Commission 2014) and from time to time, the media focus on the ill effects of unplanned rapid growth. Inevitably, the experience of LDC is not homogenous with vigorous debates regarding who benefits and who loses through long distance work arrangements varies.

Since the 1960s there have been several mining booms, during which the lack of housing, inadequate infrastructure and poor service delivery were blamed for industry inefficiencies, dysfunctional communities and disjointed economic development. The most recent, prolonged boom has amplified the pressures on housing, infrastructure, human resources and public service provision (Senate 
Select Committee on Housing Affordability in Australia 2008; Haslam McKenzie and Rowley 2013; Nicholas and Welters 2016). LDC is an easy antidote to the accommodation, infrastructure and service shortages experienced in many regional areas, but it does not solve the problem of inadequate infrastructure or poor planning for population and industry booms. In Western Australia after more than two decades of a prolonged mining boom with all the accompanying accommodation and infrastructure shortages (Haslam McKenzie 2007; Haslam McKenzie and Hoath 2014), there are still housing shortages and service shortfalls while LDC continues to by-pass underresourced towns (Haslam McKenzie 2020b). Census questions that more accurately record time spent in blocks of time at different locations and for what purpose would greatly assist planning for a range of services and infrastructure, and enable communities to better prepare for the market cycles of the resources industries.

There has been some research undertaken on second home ownership, particularly as it relates to sea/tree change communities (Paris 2013; Hugo and Harris 2013) and some of the shortcomings of inadequate or inaccurate data highlighted in this work certainly applies to LDC host communities. However, the latter communities' concerns and frustrations are not the same as communities with a large proportion of second homes, many of which are under-utilised for much of the year. Rather than episodic demands, LDC host communities have prolonged over-utilisation and/or shortages of infrastructure and services.

Nonetheless, as noted by McKenzie et al. (2008 p. 54) "funding processes for the provision of local infrastructure and services are typically based on the size of local populations. In most cases a measure of resident - as distinct to mobile - population is used". Importantly for community development and in line with the principle of horizontal fiscal equalisation (ensuring that average standard of living is achieved regardless of location across the nation), funding from central government to enable basic infrastructure and service provision is allocated via untied grants. These grants are based on population and therefore demographic data originally sourced from the census. It is therefore clear that communities with a high proportion of second home owners, LDC workers and transient worker accommodation are not receiving an equitable share of grants commission funding, despite usually having to provide many of the services and infrastructure commensurate with the overall population resident throughout the year. The inevitable shortfall puts the host communities at a significant disadvantage, carrying the costs of worker mobility with limited opportunities to disrupt the cycle (House of Representatives Standing Committee on Regional Australia 2013). The conundrum is aptly captured by McKenzie et al. (2008 p. 63):

If people are assumed to be connected to a single location and the infrastructure and service funding is allocated on a place-based per capita measure, then people living across two locations will receive less than a full service if they had been living in one location and counted as such. As they are absent, from time to time, from the location in which they are deemed to be living all of the time, then they cannot realise the services provided for them. In the second location in which they habitate, a location where they were not counted as residing and therefore were not provided infrastructure and service funding, there will be crowding and they and the locals (those counted as residents) will complete for fewer resources as there are more people wanting to access these resources. 
From an individual perspective, research consistently identifies the range of individual circumstances guiding work choices and decisions about where to live. These decisions are diverse and include specificity and level of experience and qualifications, time of life and family demands, the economic robustness of the local place of residence, availability and range of local employment options, and priority given to residing in a specific locality for natural and lifestyle amenity. The data collected about individuals' socio-economic profiles, spending and investment patterns are usually collected via focus groups, interviews and small-scale surveys, with the results often extrapolated to the broader LDC population. However, a reliable and systematic accounting of population and workforce mobility would ensure accuracy of demographic data for policy and planning, enabling all spheres of government and community development practitioners to more accurately predict demand for future services and infrastructure. It would also provide useful insights to policy makers regarding how different interventions and policies could influence labour supply, housing and accommodation needs, demand for services and infrastructure, thus ensuring a more equitable and fair means of distributing general revenue to host communities bearing the brunt of the costs associated with LDC and mobility more generally.

\section{References}

ABS (2007) Census of Population and Housing: ABS Views on Content and Procedures, 2011. Canberra: ABS. https://www.abs.gov.au/AUSSTATS/abs@.nsf/Lookup/2007.0Main+Features12011?OpenDocum ent

ABS (2012) Census of Population and Housing. Canberra: ABS. https://www.abs.gov.au/websitedbs/censushome.nsf/home/historicaldata2011?opendocument \&navpos $=280$

ABS (2020) National, state and territory population. March 2020. Canberra: ABS. https://www.abs.gov.au/statistics/people/population/national-state-and-territorypopulation/mar-2020

Carson D, Ensign P, Rasmussen R, \& Taylor A (2011) Perspectives on 'Demography at the Edge'. In: Carson D, Rasmussen R, Ensign P, Huskey L \& Taylor A (eds.) Demography on the Edge: Remote Human Populations in Developed Nations. Farnham: Ashgate; 3-20.

Cheshire $L$ (2010) A corporate responsibility? The constitution of fly-in, fly-out mining companies as governance partners in remote, mine affected localities. Journal of Rural Studies 26(1): 12-20. https://doi.org/10.1016/i.jurstud.2009.06.005

Department of Jobs Tourism Science and Innovation (2021) Western Australia: Economic profile. Perth: Government of Western Australia.

Ellem B \& Tonts M (2017) The global commodities boom and the reshaping of regional economies: The Australian experience. Australian Geographer 49(3): 383-395. https://doi.org/10.1080/00049182.2017.1388761

Fleming D \& Measham T (2015) Local economic impacts of an unconventional energy boom: The coal seam gas industry in Australia. The Australian Journal of Agricultural and Resource Economics 59(1): 78-94. https://doi.org/10.1111/1467-8489.12043

Greer L \& Stokes K (2011) Divorce and separation in the Australian mining sector: Is it what we expect? The Annual Conference of The Australian Sociological Association. Rockhampton. https://hdl.handle.net/10018/918860 
Haslam McKenzie F \& Hoath A (2014) The socio-economic impact of mine industry commuting labour force on source communities. Resources Policy 42: 45-52. https://doi.org/10.1016/i.resourpol.2014.09.002

Haslam McKenzie F \& Rowley S (2013) Housing market failure in a booming economy. Housing Studies 28(3): 373-388. https://doi.org/10.1080/02673037.2013.759177

Haslam McKenzie F (2007) Attracting and Retaining Skilled and Professional Staff in Remote Locations. Alice Springs: Desert Knowledge Co-operative Research Centre. http://www.nintione.com.au/resource/DKCRC-Report-21-Staff-Attraction-and-Retention.pdf

Haslam McKenzie F (2016a) Long distance commuting in Australia. In: Haslam McKenzie F (ed.) Labour Force Mobility in the Australian Resources Industry: Socio-Economic and Regional Impacts. Singapore: Springer; 1-10. https://doi.org/10.1007/978-981-10-2018-6

Haslam McKenzie F (2016b) The socio-economic impacts of long-distance commuting on people and communities. In: Haslam McKenzie F (ed.) Labour Force Mobility in the Australian Resources Industry. Singapore: Springer; 11-28. https://doi.org/10.1007/978-981-10-2018-6

Haslam McKenzie F, Rolfe J, Hoath A, Buckley A \& Greer L (2013) Regions in Transition: Uneasy Transitions to a Diversified Economy involving Agriculture and Mining. Curtin Graduate School of Business, Curtin University, Perth and CQUniversity, Rockhampton. Final Report prepared for CSIRO Minerals Down Under Flagship, Mineral Futures Collaboration Cluster.

Horsley J (2013) Conceptualising the state, governance and development in a semi-peripheral resource economy: the evolution of state agreements in Western Australia. Australian Geographer 44(3): 283-303. https://doi.org/10.1080/00049182.2013.817038

House of Representatives Select Committee on Regional Development and Decentralisation (2018) Regions at the Ready: Investing in Australia's Future. Canberra: Parliament of the Commonwealth of Australia.

https://www.aph.gov.au/Parliamentary Business/Committees/House/Former Committees/Regi onal Development and Decentralisation/RDD/Final Report

House of Representatives Standing Committee on Regional Australia (2013) Cancer of the bush or salvation of our cities. Canberra: Parliament of the Commonwealth of Australia.

https://www.aph.gov.au/parliamentary business/committees/house of representatives commi ttees?url=ra/fifodido/report.htm

Hugo G \& Harris K (2013) Time and tide: Moving towards an understanding of temporal population changes in coastal Australia. Adelaide: Australian Population and Migration Research Centre at the University of Adelaide for the National Sea Change Taskforce.

Hussain R, Maple M, Hunter S, Mapedzahama V \& Reddy P P (2015) The fly-in fly-out and drive-in driveout model of health care service provision for rural and remote Australia: Benefits and disadvantages. Rural and Remote Health 15: 3068. https://doi.org/10.22605/RRH3068

KPMG for the Minerals Council of Australia (2013) Analysis of the long distance commuter workforce across Australia. Canberra: Minerals Council of Australia.

Lawrie M, Tonts M, \& Plummer P (2011) Boom towns, resource dependence and socio-economic wellbeing. Australian Geographer 42(2): 139-164. https://doi.org/10.1080/00049182.2011.569985

McIntosh A (2012) Thinking Space: Ten truths about Australia's rush to mine and the mining workforce. Australian Geographer 43(4): 331-337. https://doi.org/10.1080/00049182.2012.731297

McKenzie F, Haslam McKenzie F \& Hoath A (2014) Fly-in/fly-out, flexibility and the future: Does becoming a regional FIFO source community present opportunity or burden? Geographical Research 52(4): 430-441. https://doi.org/10.1111/1745-5871.12080.

McKenzie F, Martin J \& Paris C (2008) Fiscal policy and mobility: the impact of multiple residences on the provision of place-based service funding. Australasian Journal of Regional Studies 14(1): 53-71. https://www.anzrsai.org/assets/Uploads/PublicationChapter/245-McKenzieetal.pdf. 
Nicholas C \& Welters R (2016) Exploring determinants of the extent of long distance commuting in Australia: accounting for space. Australian Geographer 47(1): 103-120. https://doi.org/10.1080/00049182.2015.1090300.

Nicholas C \& Welters R (2017) What drives long distance commuting into Australian regions? A spatial panel model approach. Journal of Rural Studies 49: 140-150. https://doi.org/10.1016/i.jrurstud.2016.11.016.

Paris C (2013) Is anybody listening? The impact of second home ownership on local governments in Australia and elsewhere. Proceedings of the 3rd National Local Government Researchers' Forum. Adelaide: Australian Centre of Excellence for Local Government.

Pilbara Development Commission (2012) Transient worker accommodation in the Pilbara. Karratha: Government of Western Australia.

Productivity Commission (2014) Geographic Labour Mobility. Canberra: Australian Government Productivity Commission. https://www.pc.gov.au/inquiries/completed/labour-mobility/report.

Productivity Commission (2019) Remote Area Tax Concessions and Payments: Issues Paper. Canberra: Productivity Commission. https://www.pc.gov.au/inquiries/completed/remote-tax/issues.

Queensland Government Statistician's Office (2020) Bowen Basin population report 2020. Brisbane: QGSO. https://www.qgso.qld.gov.au/issues/3366/bowen-basin-population-report-2020.pdf.

Queensland Treasury (2020) About the Queensland economy. Brisbane: Queensland Government. https://www.treasury.qld.gov.au/queenslands-economy/about-the-queensland-economy/

Senate Select Committee on Housing Affordability in Australia (2008) A good house is hard to find: Housing affordability in Australia. Canberra: Commonwealth of Australia. https://www.aph.gov.au/Parliamentary Business/Committees/Senate/Former Committees/hsaf Lreport/index.

Storey K (2016) The evolution of commute work in the resource sectors in Canada and Australia. The Extractive Industries and Society 3(3): 584-593. https://doi.org/10.1016/j.exis.2016.02.009.

Western Australian Legislative Assembly Education and Health Standing Committee (2015) Inquiry into mental health impacts of FIFO work arrangements. Perth: Western Australian Legislative Assembly. http://resources.news.com.au/files/2015/06/19/1227405/202450-fiforeport2.pdf. 